\title{
The concept of social liberalism of Frederick August von Hayek
}

\section{KEYWORDS}

liberalism, democracy, equality, individualism, freedom, spontaneous order, freedom, functions of law

\begin{abstract}
Emilia Wieczorek, The concept of social liberalism of Frederick August von Hayek. Culture - Society - Education no. 1(19) 2021, Poznań 2021, pp. 97-110, Adam Mickiewicz University Press. ISSN 2300-0422. DOI 10.14746/ kse.2021.19.7
\end{abstract}

According to some criteria, social liberalism is considered to be one of the types of liberalism. These studies are a reflection on Frederick August von Hayek's concept of social liberalism, who is a supporter of political and economic freedom, but above all, individual freedom. This analysis aims to present the leading ideas of his social philosophy in the area of the function of the state, democracy, freedom, spontaneous order of individualism and equality.

\section{Frederick August von Hayek - biographical findings}

Friedrich August von Hayek was born on 8 May 1899 in the Austrian capital, Vienna. He came from an affluent and educated family. His father was a doctor in the State Health Service and a lecturer in geography and botany at the University of Vienna. His brothers were professors of anatomy and chemistry. With the outbreak of World War I, Friedrich von Hayek joined the Austro-Hungarian army. He did not suffer any serious injuries while serving on the Italian front, and was awarded for his activities. After the war, he began his education at the renowned University of Vienna. His broad interests led him to study as many as four facul-

\footnotetext{
* ORCID https://orcid.org/0000-0002-5523-1506.
} 
ties: economics, psychology, law and political science. His passion for science and perseverance contributed to the fact that he graduated with a doctorate in law and political science.

Hayek's views were formed during the time of his studies. Initially, he presented socialist views, but after numerous speeches by Ludwig von Mises and Friedrich von Wieser, his beliefs changed significantly. It should be pointed out that the aforementioned authors represented the so-called 'Austrian school. Undoubtedly, the numerous speeches and contact with Mises' and Wieser's philosophy resulted in the fact that in their final form Hayek's views were so important that he himself became the most significant representative within this trend and thus a significant figure in what became known as the new Viennese school.

The 1920s were a period of great popularity for Hayek, which was the result of the economic doctrines he proclaimed. It is worth pointing out that his key opponent during this period was J.M. Keynes. 1938 brought the annexation of Austrian territory to the German Reich. On the basis of these events, Hayek chose British citizenship, and soon, after just a few years, he became an appointed member of the British Academy. At the age of 85, in 1974, he received the Nobel Prize. It was awarded to him for his overall work on the concept of monetary and economic fluctuation, as well as for a detailed study of the correlations between economic, social and institutional phenomena. The Nobel Prize was not the only accolade he received for his work. However, it brought him unquestionable fame (Brożek, 2016: 2-5). It is worth pointing out that on the basis of English-speaking sources, Hayek's achievements are described with great respect and appreciation:

The Academy is of the opinion that von Hayek's analysis of the functional efficiency of different economic systems is one of his most significant contributions to economic research in the broader sense. From the mid-thirties he embarked on penetrating studies of the problems of centralized planning. As in all areas where von Hayek has carried out research, he gave a profound historical exposé of the history of doctrines and opinions in this field. He presented new ideas with regard to basic difficulties in "socialistic calculating", and investigated the possibilities of achieving effective results by decentralized "market socialism" in various forms. His guiding principle when comparing various systems is to study how efficiently all the knowledge and all the information dispersed among individuals and enterprises is utilized. His conclusion is that only by far-reaching decentralization in a market system with competition and free price-fixing is it possible to make full use of knowledge and information ${ }^{1}$.

${ }^{1}$ Material available online: https://www.nobelprize.org/prizes/economic-sciences/1974/pressrelease/, accessed: 4.05.2020. 
Friedrich August von Hayek died in 1992, at the age of 103, in Freiburg im Breisgau.

\section{Key social concepts in the scientific activities of Friedrich August von Hayek}

Social liberalism is also known as cultural and moral liberalism. It is seen as a set of views on private life and culture. It emphasizes opposition to state interference in the private life of citizens. It also opposes social oppression which, through marginalisation, exclusion and even, in extreme cases, annihilation has led to a reduction in individual self-expression. A common example of social liberalism is opposition to state regulations which focus on art, sexual behaviour, contraception and gambling. On the basis of the subject literature:

(...) the so-called social liberalism, also defined by such adjectives as: social, new, reforming, radical, modern, revisionist, statist or progressive. This type of liberalism is characterised by the combination of liberalism with democracy and social justice, and today, thanks to e.g. John Rawls, Richard Rorty, Bruce and John Gray, the search for institutions that guarantee stable peaceful coexistence and cooperation in a single political society of people with different visions of good life (Sepczyńska, 2014: 464, also see: Kwaśnicki, 2000: 86, also see: Rau, 2000: 66-86, also see: Sepczyńska, 2010: 199-202).

Friedrich August von Hayek is presented in the literature as an outstanding and unquestionable promoter of liberal thought. Analysing the whole of the author's work, there is no doubt that his theoretical system is a network of connections between such notions as democracy, liberalism, free market, community in an atomistic perspective, negative and positive freedom, neutrality, and ethics. The analysis of Hayek's concept of social liberalism in these discussions will be based on the predominant ideas in the concept, which are presented in Figure 1.

\begin{tabular}{|l|l|l|}
\hline DEMOCRACY & $\begin{array}{l}\text { FUNCTIONS } \\
\text { OF THE STATE }\end{array}$ & FREEDOM \\
\hline LIBERALISM & INDIVIDUALISM & SPONTANEOUS ORDER \\
\hline EQUALITY
\end{tabular}

Figure 1. Leading ideas in Friedrich von Hayek's concepts of social liberalism Source: own study 
The aim of these considerations is therefore to analyse the key ideas in Hayek's social philosophy in the area of the functions of the state, democracy, freedom, the spontaneous order of individualism and equality.

\section{Freedom}

Considering the key social concepts in Friedrich August von Hayek's scientific activity requires noting that the author referred to two liberalist trends. The first trend, the continental one, is characterised by a rationalist profile. The second trend, the Anglo-Saxon, advocates tradition, customs and religious and moral values established in culture. Hayek also made a unique distinction between two types of freedom and thus pointed to freedom of the following nature: individual-personal and socio-political. It should also be stressed that the author distinguished two commonly known forms of freedom (Musiał, 2012: 280-281). The basic difference between the two areas indicated by the author is that the first negative freedom - should be seen as "freedom from", while the second - positive freedom - is understood as "freedom to". Negative freedom, which was supported by Hayek, focuses on the original liberal idea of freedom understood as the absence of external compulsion. In the author's opinion, external obstacles may restrict the individual only when they take on a social character and an arbitrary form of compulsion (Musiał, 2012: 281). Therefore, "freedom from" is understood as the absence of compulsion on the part of other individuals or institutions of a social and economic nature. It is a kind of marking of the lack of state authorities' interference in the private spheres of civic life and leaving the individuals who form society with the freedom to decide for themselves how to implement various aspects of life. It is worth stressing at this point that negative freedom is, in the author's view, characterised by the sanctioning of social and economic inequalities, and is inevitably linked to cumulative justice. This justice is created by itself, through the market, without human activity. Without the absence of an obstacle or external coercion, negative freedom gives the individual the opportunity to achieve individual goals. Analysing the meaning of a negative value allows one to observe a certain conflict of meaning. On the one hand, it has been described as negative, but the ideas it speaks of have a positive connotation. It is worth pointing out at this point that negative freedom is a necessary condition for the existence of a positive value, which means the possibility of choosing from certain options.

This understanding of positive freedom allows for a kind of identification with democracy. It should be pointed out here that, on the one hand, it gives citizens the right to assembly, to take part in elections and to influence power, but, on the other, it restricts individual freedom for the sake of equality and justice. It can there- 
fore be stated with all conviction that it offers a material existence, but in an elementary form. It also affects increased egalitarianism in income distribution. We can also equate equal opportunities in life with positive freedom, but, it is worth pointing out that this affects the processes of the market mechanism. Thus it leads to frequent conflicts and to a certain idea being imposed on a social group, which is considered to be the only right and proper one. There is, therefore, a threat of majority despotism in this area of freedom and, as Walter notes, if power is in the hands of a clerical-statist apparatus that does not come from free choice, then we can talk about succumbing to the influence of the ruling elite, which, in consequence, means a threat to democracy (Walter, 2010: 1).

Friedrich August von Hayek, shaped by the views of Ludwig von Mises, who spoke of freedom in the following manner: "Man is free as long as he is free to choose the objectives and means to achieve them" (Mises, 2007: 242) and "We can therefore define freedom as a situation in which government coercion does not restrict the freedom of decision of individuals more than praxeological law" (Mises, 2007: 243), remained, under Mises' influence, a supporter of the free market. When speaking of the concept of social liberalism in Hayek's view, we should point to his The Constitution of Liberty. It is based on this Constitution that freedom manifests itself in a situation in which: "(...) the individual has a private sphere; that there is a set of conditions around him or her in which others cannot interfere" (Hayek, 2006: 27).

Based on the author's considerations contained in the The Constitution of Liberty, freedom should be seen as an activity in accordance with one's own will and beliefs, which is not transposed through the prism of the will of others. The author points out that only such circumstances are conducive to making maximum use of the potential of the human individual, which is not indifferent to the whole of society. This is justified by the conviction that society is made up of individuals. If, therefore, we allow individuals to develop unhindered within the framework of knowledge, competences and skills, then we contribute to the development of society as a whole. What is crucial in this regard is the idea of not equating freedom with wealth. As the author points out, freedom is a sign neither of wealth nor life in happiness. It is therefore up to the individual's abilities and personality predispositions to determine in what direction his or her freedom will develop and whether he or she will thus contribute to the development of the whole of society (Hayek, 2006: 31-32).

There is no doubt that the 1960 The Constitution of Liberty focuses, as the title itself indicates, on the ideal of freedom. However, it is worth pointing out an extremely interesting aspect in this area. In this book, Hayek stressed the significant 
role of the struggle of ideas in the field of economics. He also stressed the need for at least one generation to pass, in order to win the war against Marxism and socialism, in which state planning and Keynesian interventionism are also opposed (Musiał, 2012: 288). On the basis of these considerations, Raymond Claude Ferdinand Aron's polemic with Frederick August von Hayek becomes very interesting. Aron pointed out that:

The ideal of a society in which everyone would choose their gods and their values can only become widespread when individuals are already brought up for collective life. Hayek's philosophy assumes, by its very definition, that the results, which the philosophers of the past considered to be goals of political action, have already been achieved. In order for every person to have a private sphere of decision and choice, it is first necessary that all or most people want to live together and consider the same system of ideas and the same formula of legitimacy to be true. For society to be free, it must exist (Aron, 1972: 211).

In this polemic, it is clear that democracy is the natural environment for liberalism. Totalitarianism, on the other hand, in a similar way to the considerations on social atomisation, is treated as destructive for society. It can therefore be considered that it is an autotelic matter to reconstruct common values that should be identified with the rehabilitation of the individual, for individuals can only find space for individual independence on the grounds of a renewed community. Therefore, the cornerstone of liberalism on the basis of these considerations is an independent individual, equipped with rights (Musiał, 2012: 288)

An important issue that Hayek raises in the context of freedom is the inability to understand it without a kind of confrontation with coercion, which is an indisputable expression of its denial. However, it is not possible to eliminate coercion completely, and as Hayek points out: "coercion can only be kept to a minimum if individuals can be expected to accept as a rule to act in accordance with certain principles" (Hayek, 2006: 62). This is the result of the monopoly that the state received from a free society, which resulted in the government's strict limits on power (Hayek, 2006: 34). It is therefore worthwhile, following Hayek's example, to reflect on the very essence of coercion. It exists for a specific purpose, which can be understood as protecting the individual from the domination of others. The coercion in question should be characterised by a certain amount of wisdom and should be based on a properly constructed legal system that guarantees freedom. Unquestionable coercion against the law, understood as a set of norms and values properly sanctioned by a developed and conscious society, is an autotelic value in the pursuit of facilitating social coexistence. This is done by giving order to the diverse, often uncoordinated and chaotic activities of individuals. Therefore, when 
considering the system of rights in the context of freedom in its broadest sense, a certain dualism should be pointed out. On the one hand, this system restricted individual freedom, while on the other hand, it guaranteed freedom for the general public. To sum up, on the basis of these considerations, there is a correlation between the freedom of the individual and the voluntary non-compliance with applicable standards and principles (Zagóra-Jonszta, 2018: 247).

Speaking of freedom, Hayek points to its various variations: political freedom, internal freedom and a freedom that allowed all activities to take place. Political freedom, as the name itself indicates, allows for the free election of rulers, active participation in law-making, and the absence of stigma imposed by other countries. Internal freedom, which is very individual, manifests itself in undertaking a variety of activities, but in accordance with individual will and consciousness, and therefore there is no doubt that it results from human reason. According to Hayek, the latter type of freedom is relatively dangerous. This is the result of the identification of freedom with the concept of possibility. The danger which Hayek refers to is manifested in the socialist exhortation to renounce freedom in its own name. As he concluded, individual freedom has been turned into a concept of: "collective control of conditions, and freedom in totalitarian states is suppressed in the name of freedom" (Hayek, 2006: 30). Such considerations have led Hayek to express a bold thesis about the superiority of economic freedom, without the presence of which other types of freedom have no raison dêtre. As he wrote in The Road to Serfdom, economic freedom has focused on giving freedom and choice, with a certain risk of errors and their consequences (Hayek, 1996: 107).

\section{Equality}

Friedrich August von Hayek is the author of many eminent books, but the publication of The Road to Serfdom in 1944 particularly contributed to the popularization of his thought. The author focused on justice in its broadest sense. It is therefore worth pointing out at this point that Hayek was definitely not in favour of cultivating such a term as social justice. He argued that the implementation of such a term inevitably leads to antisocial behaviour. It can therefore be assumed that on the basis of the author's considerations: "The term social justice, like 'moral stone, does not fall into the category of error but into the category of nonsense" (Olszewski, Zmierczak, 1994: 378). The justification for this claim can be found directly in Hayek's conviction that this justice is a concept that applies directly to every individual. It is not possible to talk about justice in this way in relation to the market or society as a whole. The basis for social development, and therefore free individuals, is their equality before the law. Justice understood in this way shows that profitable 
redistribution from one individual to another is contrary to both the definition of justice and, moreover, to the development of society. The basic scientific message of Hayek's activities in this area is relatively easy to read and is based on the conviction that it is not prosperity or the sacrifice of justice that is the autotelic aim of any legal and political system. The aim, however, is to be fair, which is only possible in an area of freedom under the rule of law. Hayek also pointed out that income inequality is also fair. However, it has a much more significant aim, and that is to be a factor that encourages and determines individuals' development. Therefore, by placing emphasis on this kind of justice and in order to protect individual human freedom from the actions of enserfing forces, laws should be established. However, they must be characterised by certain principles, thus upholding fundamental freedom. In this regard, Hayek has formulated three of its autotelic principles. Firstly, it should be abstract and general. Secondly, it should be universally known and simple. Thirdly, according to the Roman principle: Dura lex, sed lex, it should be applied equally to all individuals² (also see: Hayek, 2006, also see: Hayek, 1996).

\section{Spontaneous order}

Another plane is spontaneous order, which has been analysed in detail by Hayek (Hayek, 1998: 6-41, 89-104). As he indicates, the central point in the area of his social philosophy is the issue of knowledge. He focused on this particular issue when talking about the overall theory of civilisation. In the context of Hayek's deliberations we can speak of two types of knowledge. Firstly, decentralized knowledge, which concerns specific circumstances of time and place. It can be said to have a dispersed nature among individual entities. The second type of knowledge, referred to as centralised knowledge, is of an abstract and general nature, which can be applied to scientific knowledge. It should be stressed at this point that, on the basis of Hayek's work, we see decentralised knowledge as superior to centralised knowledge. In his reflections, the author referred to the conviction that no human mind (individually) is able to accumulate such resources that would allow to organize complex structures such as: social institutions, language, money, market, morals or society. According to Hayek's assumptions, it is during unconscious adaptation that an individual accumulates and transmits patterns. Individuals adapt without knowing the cause and effect relationships: individual $\leftrightarrow$ society (Machaj, 2013: 45-61).

The concept of spontaneous order, which has already been mentioned, has replaced the previously popular term "balance". The idea in question is indicated

\footnotetext{
2 Material available online: http://www.prokapitalizm.pl/neoliberalna-obrona-wolnego-rynkuw-mysli-ludwiga-von-misesa-i-fryderyka-von-hayeka/, accessed: 1.05.2020.
} 
in the literature as one of the leading ideas in Hayek's scientific activity. Its basic message is that individuals who are market participants are entangled in some kind of relationship. Therefore, it is possible to talk about establishing relations in a supra-local dimension. However, the existence of these ties is a testimony to the social mobility of individuals who do not know each other. They spontaneously undertake a number of different activities together, because they have a unanimous desire to exchange the effects of their actions. Individual products are coordinated through economic activities and processes, which makes it possible to conclude that market society is an open structure. It is worth pointing out that within an open society it is not possible to obtain a convergence of the objectives that are formulated by the individuals that constitute society. An extremely interesting polemic concerning the image of order in Hayek's works perceived as a result of spontaneous evolution was conducted by Z. Leśkiewicz, who is a methodologist of social processes. He pointed out that:

The image of the real society, as Hayek presents it, is quite pessimistic. Neither the elite nor the political structure, nor the majority, nor traditional market power, i.e. business, are faithful to the values of spontaneous evolution. Hayek underlined this in the following passage: 'Does this mean that freedom is only appreciated when it is lost, that the world has to go through the black phase of socialist totalitarianism everywhere before the advocates of freedom regain their strength? Perhaps that is the case, although I hope it does not have to be. If we are to avoid such a development, we must be able to present a new liberal programme that will attract the imagination (Leśkiewicz, Leśkiewicz, 1999: $124-125)^{3}$.

It is worth pointing out at this juncture that Hayek uses the notion of silent knowledge, which is the result of processes that are not characterised by an adaptive and selective character. This means that they limit an individual's freedom of action and allow his or her mistakes to be corrected. It should also be noted that, in G. Musiał's opinion, Z. Leśkiewicz's reflections presented above must have constituted: "an attempt to formulate a readiness to work on a new, substantive, liberal axiological order” (Musiał, 2012: 283).

\section{Individualism}

Another area that should be highlighted in these considerations is Hayek's approach to individualism. He points to its two types: "true" and "false". Each of the

\footnotetext{
${ }^{3}$ In the analysis, Z. Leśkiewicz refers to a fragment of F.A. von Hayek's considerations: Studies in Philosophy, Politics and Economics, The University of Chicago Press, Chicago 1980, p. 194 (also see: Musiał, 2012).
} 
types of individualism indicated by Hayek allows the stereotype of negative connotation to be broken, which indicates the identification of individualism with egoism. The former, true individualism, is in the simplest sense a theory of society. It is an attempt to understand the forces which determine people's social life. Then there are sets of political maxims derived from this concept of society. As Hayek points out, there is no truth in the belief that true individualism postulates the existence of isolated and self-sufficient individuals, instead of recognising as a basis people whose individual character and nature are constituted, within the framework of existence, in humanity. When considering individualism, it should be pointed out that it does not constitute an apology for egoism or isolation of being. The author himself pointed to the danger that stems from manifestations of selfishness and the atomisation of society, understood as the disintegration of social bonds, directly caused by excessive individualism. The second type, "false" individualism, indicates the possibility of a free and autonomous individual. His or her basic task, together with other entities, is to create such a social order which will be based on the principles of abstract rationality and the creation of reason. Therefore, there is no doubt that individualism understood in this way focuses on the search for such a personality, which is the result of rejecting both conventions and social habits, and is also the result of conscious choices made by the individual. Therefore, the difference between the first and second type of individualism is relatively clear and concentrated between knowledge: "describing the essential elements of the order we discover in human affairs as an unforeseen result of individual actions and a concept that reduces any detectable order to a conscious project" (Hayek, 1998: 21).

An important conclusion at this point is that the theory of individualism developed by Hayek is consistent with the thesis that it is the individual who is the original decision-maker. To sum up the considerations on the subject of individualism, it is worth pointing out that the inspiration for "real" liberalism were the views of such authors as J. Locke, D. Hume, A. Smith or E. Burke. However, as Hayek points out, "false" liberalism originates from works that remain in the Cartesian rationalist trend and here we can point to encyclopaedists and physiocrats (Cudowska, 2009: 200).

\section{Democracy}

The idea of democracy is also an important issue for consideration. Hayek's deliberations often focused on the subject of freedom. It has been accepted that democratic governance should be the guarantor of the freedom of every individual. Though democracy is not an impeccable system, it does seem to be the best one 
developed to date. This is because it appears to be a method of peaceful change. Another argument is that it seems to be an effective method of educating the majority. Hayek pointed out that: "the direction of evolution in the long run is given by ideas, and therefore by the people who disseminate them" (Hayek, 2006: 121). In considering democracy, which plays a significant role in the concept of social liberalism, it should be stressed that it does not give the right to create a law dedicated to a specific group in power. Therefore, according to the author, an individual should not: "be afraid of any universal laws that the majority may introduce, but has many reasons to be afraid of the ruling elites that the majority may impose to follow their instructions" (Hayek, 2006: 124). This claim is based on Hayek's belief that what seems to be good for the general public is not necessarily always good. The essence of the idea of democracy derives from the assumption that power (government) must be born in a spontaneous and independent process (Hayek, 2006: 117). It should be strongly emphasised here that this process is characterised by a long and stable legal framework. However, the direction of evolution is determined by ideas behind which there are politicians, historians and intellectuals in the broadest sense. Hayek pointed out that:

People rarely know or care whether the widely accepted ideas of their time come from Aristotle or Locke, Rousseau or Marx, or from some professor whose views were fashionable among intellectuals twenty years ago. Most of them have never read works or even heard the names of authors whose thoughts and ideals have become part of their own thinking (Hayek, 2006: 121).

\section{Functions of the state}

The last of the planes analysed is the functions of the state. These were in Hayek's area of interest in connection with the growing popularity of economic interventionism and the welfare state. He clearly pointed out that the welfare state often focuses on problems other than law and order. The welfare state is therefore identified with the pursuit of social policy. In connection with protection and support aimed at the poor, people with disabilities and those struggling with other adversities, the welfare state also undertakes educational and health-related activities. Hayek stressed that there are no rational arguments to exclude a proportional increase in the state's welfare activities as prosperity increases. There is also no rational justification for the impact of a state role or initiative in areas of social life such as social security, education or temporary subsidisation of experiments (Hayek, 2006: 255). Hayek pointed out that state interventionism is a tangible manifestation of the threat to individual freedom. However, he gave 
permission in his deliberations for such actions on the part of the government, which were to focus on meeting common needs resulting from both social and economic inequalities. Nevertheless, these objectives can only be achieved by redistributing income. As Hayek pointed out, it is difficult to speak of the damage caused by such actions, because it is not the objectives, but the methods used by the state that may prove problematic. Hayek showed his acceptance of the individual objectives of the welfare state, provided, however, that only such methods are used that do not lead to the restriction of the individual and the enslavement of society (Hayek, 2006: 255).

\section{Conclusions}

Friedrich August von Hayek wrote:

Freedom is necessary to make room for the unpredictable; we want it because we have learned to expect many of our objectives to be met. Precisely because each individual knows so little, and especially because we rarely know who knows best, we trust that the independent and competitive efforts of many people will lead to something that we will like when we see it (Hayek, 2006: 42).

Hayek, who is an icon of neoliberal theory, has contributed greatly to the concept of social liberalism. He pointed to the correct understanding of one's own interest. He also stressed that people make the best decisions for themselves in every situation and no one else can make a better one. The role of knowledge coming from life experience was clearly articulated in his work. This experience consists of individual experiences, hence a third person is not able to possess it. Hayek pointed out that it is individual and spontaneous decisions that create order. Despite the passage of time, the issues discussed by Hayek remain constantly relevant. The author pointed out that it remains the duty of the state to make facilities available to all individuals and this should be done on equal terms. He also denied the conviction that it would be the state's duty to provide identical opportunities to achieve a particular position. In simple terms, the government should not interfere with individual, human activities. It then creates space to manage the available resources. According to Hayek, the idea of equality deserves a special position. This is because it is determined by the need for equality in relation to the prevailing legal standards and principles. It is precisely this equality that becomes a guarantee of freedom for every individual (Hayek, 2006: 211). However, what is important 
for these considerations is that there is no certainty as to the validity of all social norms and principles, which is why the rational use of one's own reason plays such an important role. However, as Hayek emphasised: “(...) if we were to give up doing everything that is not known to us, or for which we cannot find a justification, we would probably be dead in a very short term" (Hayek, 1998: 89). Another important issue for liberals and the essence that Hayek stressed is to learn from individual mistakes. This allows us to shape the level of individual responsibility for the actions taken. The author wrote about this in the The Constitution of Liberty, which has been mentioned many times: "(...) freedom does not only mean good things" (Hayek, 2006: 31), he also stressed the inextricability of freedom and making mistakes: “(..) freedom and responsibility are inseparable" (Hayek, 2006: 81). In conclusion, society does not have a raison dêtre if all people do not take responsibility for their actions. It is only in these categories that we have the opportunity to judge it.

\section{Bibliography}

Aron R.C.F. (1972), Études politiques, Paris.

Cudowska A. (2009), Wspólnota w kulturze indywidualizmu, [in:] J. Nikitorowicz, J. Muszyńska, M. Sobecki (eds.), Wspólnoty z perspektywy edukacji międzykulturowej, Białystok.

Brożek K. (2016), Hayek vs. John Keynes - nierozstrzygnięty spór dwóch „ekonomicznych gigantów”, Studia Ekonomiczne, Prawne i Administracyjne, nr 1.

Hayek F.A. von (1996), Droga do zniewolenia, transl. by K. Gurba, L. Klyszcz et al., Kraków.

Hayek F.A. von (1998), Indywidualizm prawdziwy i fałszywy, [in:] Idem, Indywidualizm i porzadek ekonomiczny, transl. by G. Łuczkiewicz, Kraków.

Hayek F.A. von (2006), Konstytucja wolności, transl. by J. Stawiński, Warszawa.

https://www.nobelprize.org/prizes/economic-sciences/1974/press-release/, accessed: 4.05.2020.

http://www.prokapitalizm.pl/neoliberalna-obrona-wolnego-rynku-w-mysli-ludwiga-von-misesa-i-

-fryderyka-von-hayeka/, accessed: 1.05.2020.

Kwaśnicki W. (2000), Historia myśli liberalnej, Warszawa.

Leśkiewicz I., Leśkiewicz Z. (1999), Zarys metodologii ekonomii, part II and III, Szczecin.

Machaj M. (2013), Kapitalizm, socjalizm i prawa własności, Warszawa.

Mises L. von (2007), Ludzkie działanie. Traktat o ekonomii, Warszawa.

Musiał G. (2012), Wiodące idee w filozofii społecznej Friedricha Augusta von Hayeka, Przegląd Filozoficzny - Nowa Seria 2(82), Warszawa.

Olszewski H., Zmierczak M. (1994), Historia doktryn politycznych i prawnych, Poznań.

Rau Z. (2000), Zarys myśli politycznej XIX i XX wieku, Warszawa.

Sepczyńska D. (2010), O relacjach logos i praxis na marginesie definicji liberalizmu, [in:] Logos i praxis. O skuteczności myślenia, A. Biegalska, M. Jagłowski (eds.), Olsztyn. 
Sepczyńska D. (2014), Liberalizm społeczny w Polsce. Przypadek Wojciecha Sadurskiego, [in:] Liberalizm nad Wisłą XIX-XXI wiek. Koncepcje - ludzie - działalność, E. Krasucki, T. Sikorski, A. Wątor (eds.), Szczecin.

Walter P. (2010), Deformacje demokracji w myśli Friedricha Augusta von Hayeka, http://www.racjonalista.pl/kk.php/s,782, accessed: 4.05.2020.

Zagóra-Jonszta U. (2018), Wolność w ujęciu Misesa, Hayeka i Ordoliberałów, Studia Ekonomiczne. Zeszyty Naukowe. Uniwersytetu Ekonomicznego w Katowicach, nr 349. 